\title{
Dynamics of socio-economic development of districts of eastern Uttar Pradesh
}

\author{
Nitin Tanwar $^{1 *}$, Sunil Kumar ${ }^{1}$, B.V.S. Sisodia ${ }^{1}$, B.K. Hooda ${ }^{2}$ \\ ${ }^{1}$ Department of Agricultural Statistics, Narendra Deva University of Agriculture and Technology, Kumarganj, Faizabad, \\ U.P., INDIA \\ ${ }^{2}$ Department of Mathematics, Statistics \& Physics, Chaudhary Charan Singh Haryana Agricultural University, Hisar, \\ Haryana, INDIA \\ *Corresponding author. E-mail: nitintanwar5@gmail.com \\ Received: March 11, 2015; Revised received: August 17, 2015; Accepted: January 1, 2016
}

\begin{abstract}
Development process of any system is dynamic in nature and depends on large number of parameters. This study attempted to capture latest dynamics of development of districts of Eastern Uttar Pradesh in respect of three dimensions- Agriculture, Social and Infrastructure. Techniques adopted by Narain et al. (1991) have been used in addition to Principal component and factor analysis. Ranking seems to very close to ground reality and provides useful information for further planning and corrective measures for future development of Eastern Uttar Pradesh's Districts. The Composite Indices (C.I.) of development in respect of 18 developmental indicators for the total 28 districts of eastern Uttar Pradesh have been estimated for the year 2010-2011. The district Barabanki was showed a higher level of development (C.I. $=0.10)$ in Agricultural development compared to Social development (C.I. $=1.12$ ) and Infrastructural development (C.I. $=0.89)$ followed by the district Ambedkar nagar (Agricultural, C.I. =0.52), (Social, C.I. =1.12) and (Infrastructure, C.I. =0.89). District Allahabad secured first position in the Social development (C.I. $=0.81)$ and second in Infrastructural development $($ C.I. $=0.34)$ as compared to Agriculture $(C . I$. $=0.93)$. District Varanasi was the most developed district in Infrastructure $(C . I .=0.10)$ as compared to Agriculture (C.I. $=0.96$ ) and Social (C.I. =0.96). As per findings of the study, the two districts Mau and Jaunpur were down in their ranking and the districts Chandauli and Maharajganj improved their ranking.
\end{abstract}

Keywords: Composite index, Developmental Indicator, Factor analysis, Principal component analysis, Socioeconomic

\section{INTRODUCTION}

Development is a dynamic concept and has different meaning for different people. It is used in many disciplines at present. The notion of development in the context of regional development refers to a value positive concept which aims to enhance the levels of living of the people and general conditions of human welfare in a region. Socio-economic developments have become one of the most important glaring and growing problems not only in developing countries but also in the most advanced countries of the World. Since some regions are economically developed but backward socially, whereas some other are developed socially and remained backward economically. Historically, India has been observing inter-state variations as far as the socio-economic, political and geographical aspects are concerned (Siddiqui, 2012).

Socio-economic development is to improve the quality of life of people by creation of appropriate infrastructure, among others, for industry, agriculture environment. Economic planning of the country is aimed at bringing about maximum regional development and reduction in regional disparities in the pace of development. Programmes of development have been taken up in the country in a planned way through various Five Year Plans. The Green Revolution in the agriculture sector and commendable progress on the industrial front has certainly increased the overall total production, but there is no indication that these achievements have been able to reduce substantially the regional inequalities in the level of development (Narain et al. 2007). Although resource transfers are being executed in backward region of country, it has been observed that the regional disparities exist in terms of socioeconomic development are not declining over time (Narain et al., 2003).

Since Independence the country has implemented various Five Year Plans and few Annual Plans for enhancing the quality of life of people by providing basic necessities for effective improvement in their social and economic well-being. Various area development programmes were launched during the fifth plan, with one of the aims to reduce regional disparities at microlevel. During the sixth, seventh and eight plans, the previous programmes of development were carried on. Presently, development programmes covering agriculture, employment generation, population control, literacy, health, environment, provision of basic amenities etc. are in the process of development. As result of six 
decades of planned development and policies, overall improvement in the economic condition has taken place. The structure of national and state economies has been changed significantly. The socio-economic condition of the masses has considerably been improved. The literacy level, housing condition, quality of life have gone up. But the level of development has not been uniformly at any level. Inter and intra-section differences in the economic structure have become more sharp and noticeable. Consequently, certain areas went ahead leaving other lagged behind (Siddiqui, 2012). The Green Revolution in the agriculture sector has enhanced the crop productivities and commendable progress in the industrial front has increased the quantum of manufactured goods. The structure of the economy has undergone certain changes. But a regional disparity has also been aggravated here which opens up a vista of research.

Agriculture is the mainstay of the majority of the population in the state. It employs about two-thirds of the workforce and contributes about one-third to the state income. While wheat is the state's principal crop, sugarcane is the state's main commercial crop, largely concentrated in the western and central belts of the state. The western region of the state is more advanced in terms of agriculture. Majority of the population depends upon farming as its main occupation. Rice, pulses, oil seeds and potatoes are other main products of the state (Narain et al. 1995).

The present study deals with the evaluation of the levels of agricultural, social and industrial developments at district level in the State of Eastern Uttar Pradesh.

\section{MATERIALS AND METHODS}

Study area: The study comprised of 28 districts of eastern Uttar Pradesh (Table 1). Each district faces situational factors of development unique to it as well as common administrative and financial factors. Factors common to all the districts have been taken as the indicators of development.

Developmental indicators: The composite indices of development for different districts were obtained by using the data on the following development indicators: Percentage of net area irrigated, Average Productivity of food grains $(\mathrm{q} / \mathrm{h})$, Per capita consumption of electricity $(\mathrm{kw} / \mathrm{h})$, Per Capita Gross Value of Agricultural Produce (Rs.), Gross Value of Agricultural Produce per Hec. of Net Area Sown (Rs.), Gross Value of Agricultural Produce Per hec. of Gross Area Sown (Rs.), Cropping intensity in percentage, No. of Private Tube wells, Number of Registered Factories per lacs population, Percentage of Electrified villages, Percentage of Literacy Rate, Number of Post offices per lacs population, Number of Telephone connections per lacs population, Number of cooperative banks, Number of Primary Schools per lacs population, Number of Junior High Schools per lacs population, Number of Intermediate colleges per lacs population, Number of Com- mercial Banks.

A total of eighteen developmental indicators have been included in the analysis. These indicators are the major interacting components of development. Out of these eighteen indicators, seven indicators are directly concerned with agricultural development and the rest eleven indicators describe the availability of social and infrastructural facilities in the districts.

\section{Method of analysis}

Method of estimation of Composite Index of development (Narain et al. 1991): Let $\left[X_{\mathrm{ij}}\right]$ be data matrix giving the values of the variables of $i^{\text {th }}$ district. Where $i$ $=1,2 \ldots \mathrm{n}$ (number of districts) and $\mathrm{j}=1,2 \ldots \mathrm{k}$ (number of indicators).

For combined analysis $\left[\mathrm{X}_{\mathrm{ij}}\right]$ is transferred to $\left[\mathrm{Z}_{\mathrm{ij}}\right]$ the matrix of standardized indicators as follows

$$
\left[\mathrm{Z}_{\mathrm{ij}}\right]=\frac{X_{i j}-\bar{X}_{j}}{S_{j}}
$$

Where, $S_{j}=$ Standard deviation of $j^{\text {th }}$ indicator $=$ mean of the $\mathrm{j}^{\text {th }}$ indicator

From $\left[Z_{\mathrm{ij}}\right]$, identify the best value of each indicator. Let it be denoted as $Z_{\mathrm{oj}}$. The best value will be either the maximum value or the minimum value of the indicator depending upon the direction of the impact of indicator on the level of development. For obtaining the pattern of development $C_{i}$ of $i^{\text {th }}$ districts, first calculate $\mathrm{P}_{\mathrm{ij}}$ as follows

$$
P_{i j}=\left(Z_{i j}-Z_{o j}\right)^{2}
$$

Pattern of development is given by

Where, $(\mathrm{CV})_{\mathrm{j}}=$ coefficient of variation in Xij for $\mathrm{jth}$ indicator.

Composite index of development (C.I.) is given by

$$
\begin{array}{r}
\text { C.I. }=\mathrm{C}_{\mathrm{i}} / \mathrm{C} \quad \text { for } \mathrm{i}=1,2, \ldots, \mathrm{n} \\
\mathrm{C}=\bar{C}+3 S D i
\end{array}
$$

Where $\bar{C}=$ mean of $\mathrm{C}_{\mathrm{i}}$ and

$$
\mathrm{SD}_{\mathrm{i}}=\text { Standard deviation of } \mathrm{C}_{\mathrm{i}}
$$

Smaller value of C.I. will indicate high level of development and higher value of C.I. will indicate low level of development.

Principal component analysis: Principal component analysis (PCA) is a multivariate technique that analyzes a data table in which observations are described by several inter-correlated quantitative dependent variables. Its goal is to extract the important information from the table, to represent it as a set of new orthogonal variables called principal components, and to display the pattern of similarity of the observations and of the variables as points in maps. Mathematically, PCA depends upon the eigen-decomposition of positive semi-definite matrices and upon the singular value decomposition (SVD) of rectangular matrices.

Goals of PCA: The goals of PCA are to extract the most important information from the data table, Compress the size of the data set by keeping only this important information, Simplify the description of the 
Table 1. Composite indices (C.I.) of development.

\begin{tabular}{llccccc}
\hline \multicolumn{1}{c}{ Districts } & \multicolumn{2}{c}{ Agricultural System } & \multicolumn{2}{c}{ Social System } & \multicolumn{2}{c}{ Infrastructural System } \\
Rank
\end{tabular}

Table 2. Rank correlation between social and industrial Structure.

\begin{tabular}{lll}
\hline & Social Rank & Industrial Rank \\
\hline Social Rank & 1 & 0.775 \\
Industrial Rank & 0.775 & 1 \\
\hline
\end{tabular}

data set and Analyze the structure of the observations and the variables.

Factor analysis: Factor analysis was used to describe variability among observed variable in terms of a potentially lower number of unobserved variables called factors (Thurstone, 1931).

\section{RESULTS AND DISCUSSION}

Level of Development: The composite indices of development have been worked out for different districts of Eastern Uttar Pradesh separately for agricultural system, social system and industrial system. The districts have been ranked on the basis of developmental indices. The composite indices of development along with the district ranks are presented in Table 1 . The results of the composite indices shows that the district Barabanki was the most developed district in agricultural system followed by the districts Ambedkar nagar and Faizabad, while in social development district Allahabad was top most developed district followed by the districts Mau and Varanasi. On the basis of infrastructure, Varanasi showed a high development among the districts under the study. District Shravasti was the most backward district in all the three dimensionsagriculture, social and infrastructural system.
In agricultural development the districts Barabanki, Faizabad and Ambedkar nagar were in top 5 districts since year 1995. Verma (2014) studied that the development at block level of districts Barabanki, Ambedkar nagar and Faizabad is highly advanced in agricultural and infrastructural system. Many other improvement trends have highlighted in the study. On the other hand, in social and infrastructural system since year 1995, Allahabad, Varanasi and Gorakhpur were also in most five developed districts. Other striking feature is that there are many new districts have been created from earlier districts since 1995 which do not allow direct comparison at district to district level. However, some significant broad trends are very informative and need careful scrutiny for understanding the underlying dynamics of period 1995-2011.

Agricultural development: The results show that Barabanki, Faizabad and Ambedkar nagar are in top 5 districts since year 1995. These districts are in top 5 positions as per the principal component analysis and factor analysis used by Rajpoot (2008) and in current study showing their consistency.

Mau and Jaunpur were in top 5 districts in year 1995 but as per observations in year 2008 and year 2011 these districts have come down in the ranking based on Foodgrains production status. Two districts, viz, Chandauli and Maharajganj are showing improvement in ranking as evaluated by the methods. The agriculture status has high correlation coefficient with-Value of the produce, number of private tube wells, irrigated 
area. High rank correlation coefficient among different methods is indicating fairly good agreement in ranking. Sonbhadra, Shravasti, Mirzapur and Sant Ravidas nagar are listed in 5 most backward districts by most of the methods used in 2008 and in current study. Sonbhadra was listed as backward in 1995 (Narain et al., 1995) and is still have not made any improvement so far. Gorakhpur, Allahabad, Ballia were listed backward in 1995 but as per status of 2008 (Rajpoot., 2008) and as per current study they have improved their status and moved up. Pratapgarh has improved its position in comparison to 1995 and 2008 status.

Social development: The results show that Allahabad, Varanasi and Gorakhpur are in top 5 districts since year 1995. Besides, these are in top 5 positions by most of the methods used in 2008 and in current study. The districts, viz, Faizabad, Jaunpur and Mau are showing improvement in ranking as evaluated by the methods in 2010. Consumption of electricity has high correlation coefficient with number of telephone connection and number of commercial banks.

Shravasti, Balrampur are listed in 5 most backward districts by most of the methods used in current study. Behraich was reported in the most 5 backward districts in year 1995 and is still at that position while districts Ballia, Azamgarh and Pratapgarh have improved their positions since 1995 as evaluated by the methods.

Industrial development: The results show that Varanasi, Allahabad, Gorakhpur and Mirzapur are in top 5 districts since year 1995. Besides, these are in top 5 positions by principal component analysis and factor analysis used in 2008 and in current study. Mirzapur and Sonbhadra were in top 5 districts in year 1995 but as per observations in year 2008 and year 2011 these districts have come down in the ranking based on Industrial development. Number of Registered factories has high correlation coefficient with per capita consumption of electricity, number of telephone connection and number of commercial banks.

Shravasti, Siddarth nagar, Balrampur and Sant Kabir nagar are listed in 5 most backward districts. Sultanpur Jaunpur and Pratapgarh were listed in top most backward districts in 1995 and there is marginal improvement in ranking of these districts. Siddarth nagar is most backward district since 1995 .

Inter-relationship among different sectors of Economy: For proper and effective development, it is desirable that social and industrial facilities should prosper together. The rank correlation coefficient between social and industrial system is more than 0.77 presented in Table No. 2 which shows Social and Industrial structures are related.

Improvement required in low developed districts: It is quite important and useful to examine the extent of improvement needed in various developmental indicators for the low developed districts. This will help the administrators and planners to readjust the resources bringing about uniform regional development.
District Sonbhadra: This district is low developed in agriculture sector. District Sonbhadra has minimum gross value of agricultural produce. It has also minimum value of cropping intensity. The above result indicates that Sonbhadra is at lowest level of development. Improvements are needed to enhance the agricultural development by creating additional value of agricultural produce per hectare of net area sown, irrigation potential and also popularizing the use of manure and fertilizer. Developmental programmes should be taken in the district.

District Shravasti: This district is low developed in social and industrial sectors. District Shravasti has minimum number of telephone connections per lakh of population, minimum number of commercial banks, cooperative banks and minimum literacy rate. The district has also minimum number of inter schools per lakh of population. The above results indicate that district Shravasti is at lowest level of development in social and industrial sectors.

District Balrampur: This district is low middle level developed in social and industrial sectors. Educational, banking and industrial facilities should be improved in this district.

\section{Conclusion}

It was observed that there are wide disparities in the level of socio-economic development of districts of eastern Uttar Pradesh. The districts Faizabad, Varanasi, Gorakhpur, Allahabad and Barabanki were classified as the most developed districts according to our classification. Three districts viz.; Shravasti, Balrampur and Sonbhadra were found to be very poorly developed with respect to overall development. Out of three most backward districts two i.e. Shravasti and Balrampur were the least developed in view of agriculture, social and infrastructural fronts. Shravasti was very poor in all the three sectors of agriculture, social and infrastructure. To attain uniform development in the eastern Uttar Pradesh individual indicators need to be examined for making them at par with their values in the developed districts. Such information may help the planners and administrators to readjust the resources allocation and priorities targets in the eastern Uttar Pradesh.

\section{REFERENCES}

Narain, P., Rai, S.C. and Shanti S. (1991). Statistical evaluation of development on socio-economic front. Jour. of Ind. Soc. of Agril. Stat. 43 : 329-345.

Narain, P., Rai, S.C. and Shanti, S. (1995). Regional Disparities in the Levels of Development in Uttar Pradesh. Jour. of Ind. Soc. of Agril. Stat. 47 : 288-304.

Narain, P., Sharma, S.D., Rai, S.C. and Bhatia, V.K. (2003). Evaluation of Economic Development at Micro level in Karnataka. Jour. of Ind. Soc. Of Agril. Stat. 56 : 52-63.

Narain, P., Sharma, S.D., Rai, S.C. and Bhatia, V.K. (2007). Statistical evaluation of socio-economic development of different states in India. Jour. of Ind. Soc. of Agril. Stat. $61(3): 328-335$. 
Rajpoot, S.S. (2008). A study on socio-economic development in eastern Uttar Pradesh. Unpublised M.Sc thesis submitted to the Dept. of Agril. Statistics, NDUA\&T, Kumarganj, Faizabad.

Verma, S. (2014). A Study on Relative Evaluation of Development of Agriculture and Infrastructure of Faizabad Division in Eastern Uttar Pradesh. Unpublised M.Sc. thesis submitted to the Dept. of Agril. Statistics, NDUA\&T, Kumarganj, Faizabad.

Siddiqui, S. (2012). Regional analysis of socio-economic development in Uttar Pradesh. African Jour. of Social Science. $2: 120-130$.

Thurstone, L.L. (1931). Multiple factor analysis. Psychological review. 38 (5):406-427. 